\title{
ロ脸外科領域におけろパトラシン細粒の臨床使用成級
}

\author{
松本意・原田利夫・吉村安郎
}

\section{Clinical evaluation of Vatracin powder in oral surgery}

\author{
Ken Matsumoto - Toshio Harada - Yasuro Yoshimura
}

粕

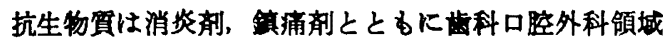
においては使用頻度の高い来用であって，その主流は現 在合成ベニシリン系とセファロスボリン系製用である.

口腔内感染应の原因となる多くの菌が合成ベニシリンに 対し感受性を有していること息2)，また耐性菌出現を防 ぐといら点からす第一選択はやはりベニシリン系製都で あろらと思われる。最近は $1.5 \mathrm{~g} /$ 日， $2.0 \mathrm{~g} /$ 日程度が常 用経口投与量となっている．本来べニシリン系薬剂は 肝，堅などへの障害が少ないとされているが小児や老 人, 各人の㑭体差も考虑し一律に投与すべきすのではな く，また老人，小児で錠剤やカブセル用の腿用に慣れて いない患者るいることを考えると、細粒といら剤型は必 要である.

今回，われわれは合成ベニシリンの AC-PC 製肪であ ろパトラシン細粒（科研薬化工株式会社）を歯科口腔外 科患者に使用する機会を得たので，その治験成絰につい て報告する。

\section{薬㶡について}

パトラシン細粒は，1 $\mathrm{g}$ 中に 日抗基シクラシリン 100 mg (力価) を含有するだいだい色の細粒である.

シクラシリンは图1の構造式を有する白色〜淡黄白色 の結晶性粉末で，水にやや溶けにくく，メタノールに溶 けにくく、エタノールにきわめて溶けにくく、フセト ン,エーテル，クロロホルムまたはベンゼンにはとんど 容けない。

シクラシリンは広範囲抗菌スペクトルを有しクラム陽 性菌および一部グラム陰性菌群に対してる殺菌的に作用

島根医科大学医学部附属病院齿科口膑外科（主任： 吉村安郎教授）

Department of Oral and Maxillofacial Surgery, Shimane Medical University (Chief: Prof. Yasuro Yoshimura)

受付日：昭和56年 1 月 7 日

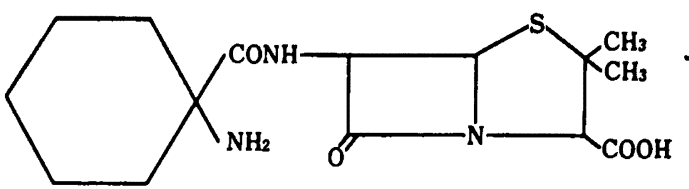

6-(1-Aminocyclohexane Carboxamido) penicillanic acid 図 1 シクラシリンの橉造式

し、ペニシリン耐性ブドウ球菌の産生するベニシリナー セに対してフンビシリンより安定である3 ${ }^{3)}$.

抗菌力はフンピシリンと比して低いか，経口投与によ り消化管より速やかに吸収され，フンピシリンよりる高

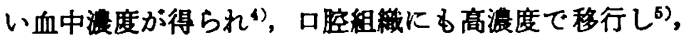
その後尿中に排泄される3゙，また下测などの副作用す少 ないる)とされている.

\section{投与対象ならびに投与方法}

島根医科大学医学部附属病院歯科口腔外科外来を昭和 55 年 8 月から昭和 55 年 10 月までの 2 か月間に受診した患 者のうち44名，46例を治験対象としたが，そのうち 3 名 は再受晾せず脱落し，最終的には41名，43症例であっ た.

投与方法はバトラシン細粒を 1 日旦 $1,500 \mathrm{mg}$ (力価)， 3 分服としたが，症例により増減量した。投与期間は 3 日から 7 日間（平均 $4.0 \pm 1.1$ 日）であり，総投与量は $2,700 \mathrm{mg}$ から $14,000 \mathrm{mg}$ (平均 $6,004 \pm 1,890 \mathrm{mg}$ ) で あった。期間中他の抗生㨈は用いず，場合により鎮痛 郕, 醇素剤を併用した。

年龄分布は13歳から77藏で平均 $38.0 \pm 14.4$ 歳であっ た（表 1 ).

症例内訳は歯根膜炎 19 例，智歯周囲炎 12 例，膿瘍 4 例, 歯周症急性発作 5 例, 埋伏智歯（無症状） 1 例, 転 位雪（無症状） 1 例，耳下腺资 1 例の43例であった。

43例中35例は観血処置（拔歯31例，“切開 4 例）を， 8 例は非観血処置（洗浄 7 例、投薬のみ 1 例）を施した。 


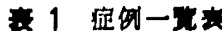

\begin{tabular}{|c|c|c|c|c|c|c|c|c|c|c|c|c|}
\hline \multirow{2}{*}{$\begin{array}{l}\text { 症例 } \\
\text { No. }\end{array}$} & \multirow{2}{*}{ 年能 } & \multirow{2}{*}{ 性别 } & \multirow{2}{*}{ 昣断名 } & \multirow{2}{*}{ 処 而 } & \multirow{2}{*}{ 日数 } & \multirow{2}{*}{$(\mathrm{mg})$} & \multirow{2}{*}{ 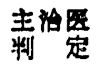 } & \multicolumn{2}{|c|}{ 既床应状 } & \multirow{2}{*}{ 3日睛初的 } & \multirow{2}{*}{ 作用 } & \multirow{2}{*}{$\begin{array}{l}\text { AC-PC } \\
\text { 㭧受性 }\end{array}$} \\
\hline & & & & & & & & 初日 & 3日目 & & & \\
\hline 1 & 47 & $\mathbf{M}$ & Per & $\mathbf{E}$ & 3 & 4,500 & $++t$ & 7 & 2 & 0.29 & - & \\
\hline 2 & 24 & $\mathbf{M}$ & Per & E & 4 & 6,000 & ++ & 5 & 4 & 0.80 & - & \\
\hline 3 & 46 & $\mathbf{M}$ & 耳下滕次 & & 6 & 9,000 & + & 5 & 2 & 0.40 & - & \\
\hline 4 & 29 & $\mathbf{M}$ & Pco & $\mathbf{S}$ & 5 & 7,500 & $++t$ & 8 & 2 & 0.25 & - & \\
\hline 5 & 29 & $\mathbf{M}$ & Pco & $\mathbf{E}$ & 5 & 7,500 & - & 2 & 6 & 3.00 & - & \\
\hline 6 & 27 & F & 埋伏 & $\mathbf{E}$ & 5 & 7,500 & - & 2 & 9 & 4.50 & - & \\
\hline 7 & 28 & F & Pco & E & 5 & 7,500 & - & 5 & 12 & 2.40 & - & \\
\hline 8 & 44 & F & Pco & $\mathbf{E}$ & 4 & 6,000 & $++t$ & 9 & 2 & 0.22 & - & \\
\hline 9 & 54 & F & 口腔底 A & I & 7 & 10,500 & + & 16 & 14 & 0.88 & - & $+t+$ \\
\hline 10 & 47 & $\mathbf{M}$ & 哏踹下A & I & 8 & 14,000 & $++t$ & 19 & 5 & 0.26 & - & $+t+$ \\
\hline 11 & 23 & F & Per & E & 3 & 4,500 & + & 8 & 7 & 0.88 & - & \\
\hline 12 & 26 & $\mathbf{M}$ & Per & $\mathbf{E}$ & 5 & 7,500 & $+t$ & 11 & 8 & 0.73 & - & \\
\hline 13 & 58 & $\mathbf{F}$ & Per & $\mathbf{E}$ & 3 & 4,400 & ++ & 4 & 2 & 0.50 & - & \\
\hline 14 & 37 & $\mathbf{M}$ & $\mathbf{P}$ & E & 4 & 6,000 & +++ & 4 & 2 & 0.50 & - & \\
\hline 15 & 47 & $\mathbf{M}$ & $\mathbf{P}$ & $\mathbf{S}$ & 3 & 4,500 & $++t$ & 9 & 3 & 0.33 & - & \\
\hline 16 & 54 & $\mathbf{M}$ & Per & $\mathbf{E}$ & 3 & 4,500 & ++ & 2 & 2 & 1.00 & - & \\
\hline 17 & 21 & F & Pco & $\mathbf{S}$ & 3 & 4,500 & + & 10 & 8 & 0.80 & - & \\
\hline 18 & 21 & $\mathbf{M}$ & Per & $\mathbf{E}$ & 5 & 7,500 & ++ & 6 & 2 & 0.33 & - & \\
\hline 19 & 42 & $\mathbf{M}$ & Pco & $\mathbf{E}$ & 4 & 6,000 & + & 9 & 9 & 1.00 & - & $+t+$ \\
\hline 20 & 27 & F & Per & $\mathbf{S}$ & 4 & 6,000 & +++ & 9 & 2 & 0.22 & - & \\
\hline 21 & 58 & $\mathbf{M}$ & $\mathbf{P}$ & $\mathbf{E}$ & 4 & 6,000 & +++ & 9 & 3 & 0.33 & - & \\
\hline 22 & 51 & $\mathbf{M}$ & 口腔底 A & I & 4 & 6,000 & - & 20 & 21 & 1.05 & - & $+t+$ \\
\hline 23 & 51 & $\mathbf{M}$ & Per & $\mathbf{E}$ & 4 & 6,000 & ++ & 2 & 2 & 1.00 & - & \\
\hline 24 & 19 & $\mathbf{M}$ & Pco & $\mathbf{S}$ & 3 & 4,500 & +++ & 10 & 3 & 0.30 & - & \\
\hline 25 & 53 & F & Per & $\mathbf{E}$ & 3 & 4,500 & ++ & 6 & 4 & 0.67 & - & \\
\hline 26 & 31 & $\mathbf{F}$ & Pco & $\mathbf{E}$ & 4 & 6,000 & - & 7 & 8 & 1.14 & - & \\
\hline 27 & 28 & $\mathbf{M}$ & Pco & E & 3 & 4,500 & ++ & 2 & 3 & 1.50 & - & \\
\hline 28 & 45 & $\mathbf{M}$ & Per & $\mathbf{E}$ & 3 & 4,500 & ++ & 5 & 5 & 1.00 & - & \\
\hline 29 & 41 & F & Per & $\mathbf{E}$ & 3 & 4,500 & +++ & 7 & 2 & 0.29 & 腹部不快忽 & \\
\hline 30 & 23 & $\mathbf{M}$ & Per & $\mathbf{E}$ & 4 & 6,000 & $+t+$ & 8 & 3 & 0.38 & - & \\
\hline 31 & 54 & F & 蕃槽 A & I & 4 & 6,000 & $+t$ & 8 & 3 & 0.38 & - & $+t+$ \\
\hline 32 & 13 & $\mathbf{F}$ & 転位米 & $\mathbf{E}$ & 3 & 2,700 & ++ & 2 & 2 & 1.00 & - & \\
\hline 33 & 77 & F & Per & $\mathbf{E}$ & 4 & 6,000 & ++ & 4 & 2 & 0.50 & - & \\
\hline 34 & 51 & $\mathbf{M}$ & $\mathbf{P}$ & $\mathbf{E}$ & 3 & 4,500 & +++ & 6 & 2 & 0.33 & - & \\
\hline 35 & 28 & F & Pco & $\mathbf{E}$ & 4 & 6,000 & +++ & 6 & 2 & 0.33 & - & \\
\hline 36 & 53 & $\mathbf{M}$ & Per & $\mathbf{E}$ & 4 & 6,000 & ++ & 6 & 2 & 0.33 & - & \\
\hline 37 & 37 & $\mathbf{M}$ & Pco & $\mathrm{E}$ & 3 & 4,500 & +++ & 6 & 2 & 0.33 & - & \\
\hline 38 & 23 & $\mathbf{F}$ & Per & $E$ & 4 & 6,000 & +++ & 7 & 2 & 0.29 & - & \\
\hline 39 & 30 & $\mathbf{M}$ & Per & $\mathbf{E}$ & 4 & 6,000 & ++ & 2 & 2 & 1.00 & - & \\
\hline 40 & 22 & $\mathbf{F}$ & Per & $\mathbf{E}$ & 3 & 4,500 & ++ & 4 & 3 & 0.75 & - & \\
\hline 41 & 51 & $\mathbf{M}$ & $\mathbf{P}$ & $\mathrm{S}$ & 5 & 7,500 & +++ & 10 & 4 & 0.40 & - & \\
\hline 42 & 47 & $\mathbf{M}$ & Per & $\mathrm{E}$ & 4 & 6,000 & ++ & 2 & 2 & 1.00 & - & \\
\hline 43 & 18 & F & Pco & $\mathbf{S}$ & 3 & 4,500 & + & 9 & 7 & 0.78 & - & \\
\hline
\end{tabular}

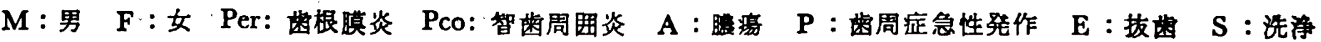
I : 切開 判定: +十+著奻, 十+有奻, 十稍有㚳, 一無奻 


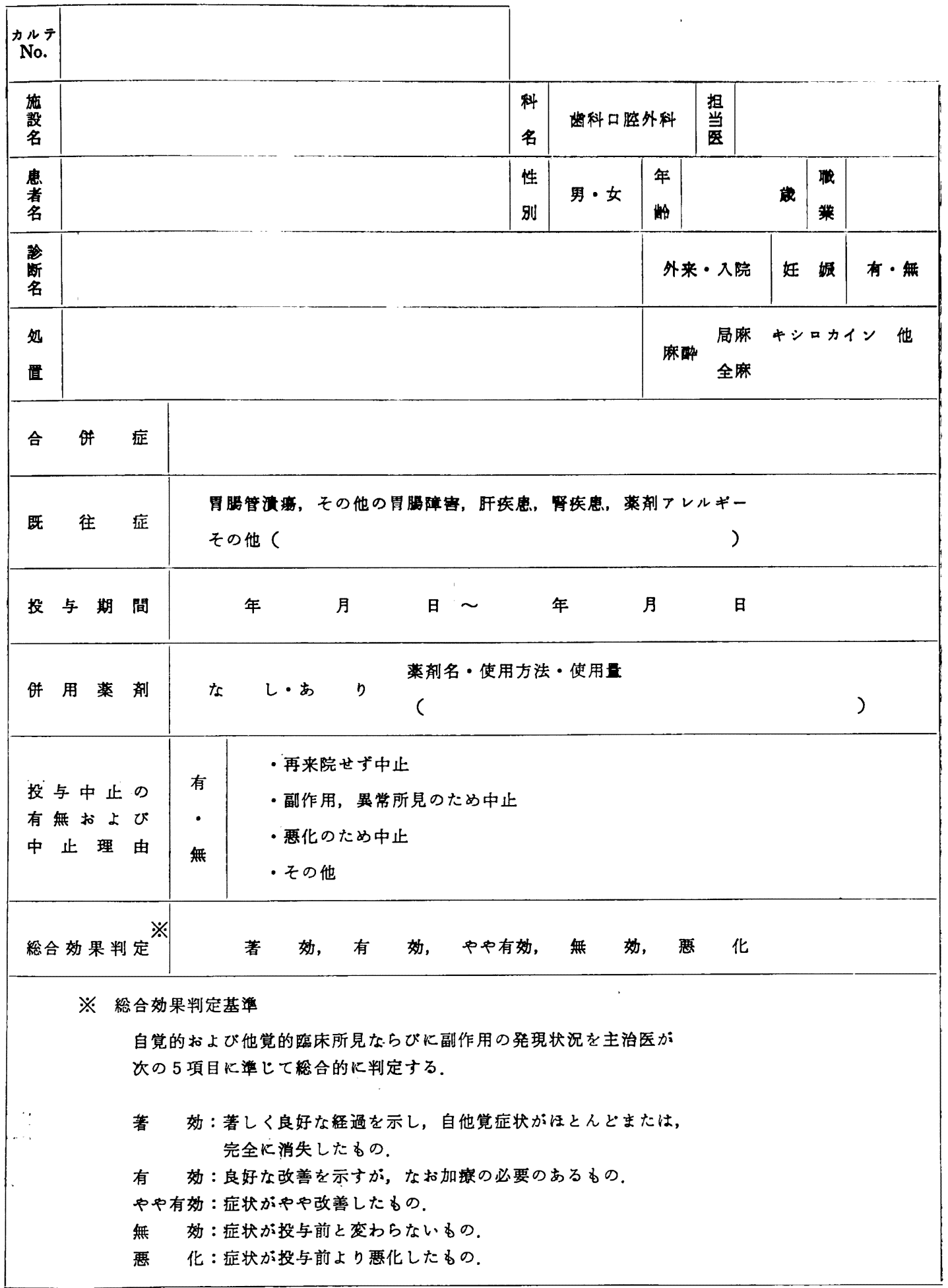




\begin{tabular}{|c|c|c|c|c|c|c|c|c|c|c|c|c|}
\hline 歴 & & & 日 & 月 日 & 月 日 & 月 日 & 月 日 & 月 日 & 月 日 & 月 日 & 月 日 & \multirow{2}{*}{1} \\
\hline 病 & & & 日 & 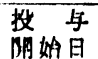 & 第 1 日目 & 策 2 日目 & 第 3 日目 & 第 4 日目 & 第 5 日目 & 1) 6 日目 & 7日目 & \\
\hline 本 & 绪投 & 与 & it & & & & & & & & & \\
\hline 併 & 用 & 菓 & 威 & & & & & & & & & \\
\hline \multirow{3}{*}{ 全所 } & 体 & & 温 & $\overline{0123}$ & $012 \overline{3}$ & 0123 & 0123 & 0123 & $01 \overline{23}$ & 01230 & 0123 & \\
\hline & 全 身 & 供 & 意 & 12 & 12 & 12 & 12 & 12 & 12 & 12 & 12 & \\
\hline & 金 微 & 不 & 振 & 12 & 12 & 12 & 12 & 12 & 12 & 12 & 12 & \\
\hline \multirow{10}{*}{$\begin{array}{l}\text { 局 } \\
\text { 所 } \\
\text { 所 } \\
\text { 見 }\end{array}$} & 一発－赤口 & 口腔 & 内 & 024 & 024 & 024 & 024 & 024 & 024 & 024 & 024 & \\
\hline & -(囌怒) & 口腔 & 外 & 012 & 012 & 012 & 012 & 012 & 012 & 012 & 012 & \\
\hline & 俨 㟲 & 口腔 & 内 & 024 & 024 & 024 & 024 & 024 & 024 & 024 & 024 & \\
\hline & & 口朣 & 外 & 012 & 012 & 012 & 012 & 012 & 012 & 012 & $01 \overline{2}$ & \\
\hline & 硬 & & 粘 & 012 & 012 & 012 & 012 & 012 & 012 & 012 & 012 & \\
\hline & \multirow{3}{*}{ 疼 痛 } & 自発 & 痛 & 012 & 012 & 012 & 012 & 012 & 012 & 012 & 012 & \\
\hline & & 整 下 & 痛 & 01 & 01 & 01 & 01 & 01 & 01 & 01 & 01 & \\
\hline & & E & 痛 & 01 & 01 & 01 & 01 & 01 & 01 & 01 & 01 & \\
\hline & 用 & 陣 & 宫 & 0123 & 0123 & 0123 & 0123 & 0123 & 0123 & 0123 & 0123 & \\
\hline & 1) ข & 節 所 & 見 & 012 & 012 & 012 & 012 & 012 & 012 & 012 & 012 & \\
\hline 局 & 所 & 妈 & 管 & & & & & & & & & \\
\hline 副 & 作 & & 用 & & & & & & & & & \\
\hline 合 & 計 & 点 & 纹 & & & & & & & & & \\
\hline
\end{tabular}

病状の採点蓄望

1. 体 温 : $0: 37^{\circ} \mathrm{C}$ 末满
$1: 37^{\circ} \mathrm{C}$ 以上 $37.5^{\circ} \mathrm{C}$ 末満
$2: 37.5^{\circ} \mathrm{C}$ 以上 $38^{\circ} \mathrm{C}$ 末满
$3: 38.0^{\circ} \mathrm{C}$ 以上

2. 全身供急: 1：なし

2 : あり

3. 食欲不振：1：なし

$$
2 \text { :お り }
$$

4. 発赤(熱感):

a口腔内：0：なし

$2: 1 \sim 2$ 歯程度の歯肉の発赤

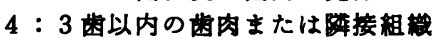

（煩粘膜，口底粘膜など）に及 んだ発赤

b 口腔外：0：なし
1 : 口腔外に発赤または熱感のある ठの
2 ：熱感を伴った発赤

5. 聥脹 :

a口腔内: $0:$ し

$2: 1 \sim 2$ 宷程度の齿肉の迎脹

4 : 3 菌以上の菌肉または隣接組織

（頓粘膜，口底粘膜など）に及

んだ連腿 b口腔外：0：なし

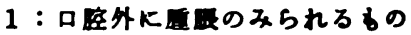

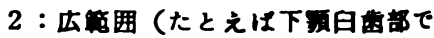

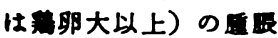

6. 不 站：0：なし

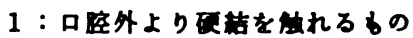

2 : 皮市の祭張を伴った原洁

7. 疼㞗：

a 自発涌：0：なし

1 : 自発有のおるもの

2 : 㴊速のあるるの

b 下蔽：0：なし

1:お り

c E 席:0:な し

8. 開口障宫：0：聞口城 $30 \mathrm{~mm}$ 以上

1 : 開口城 $20 \mathrm{~mm}$ 以上 $30 \mathrm{~mm}$ 末

2 : 開口域 $10 \mathrm{~mm}$ 以上 $20 \mathrm{~mm}$ 末陆

3:阙口域 $10 \mathrm{~mm}$ 末溚

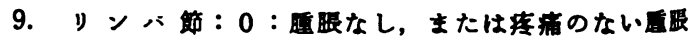

$1 ：$ 可的性で王蔽を伴った瘇卧

2 : 非可勘性で压痛を伴った盾脹

图 2 奻果判定表 


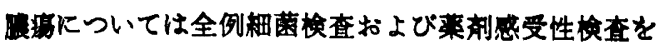
行った.

\section{効果判定および副作用の有無}

薬帏使用効果の判定は, 主治医の主钼に上る判定と, 日本口䧑外科学会の抗生物筫效果判定基遥委員会案に基 うく採点法（图2）により行った。主治医の主覞的判断 は，初日の臨床症状と，加えたとすればその外科传垬度

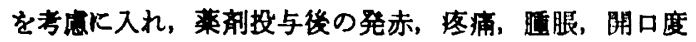
などを主体とした臨床症状を主治医が視察し，著奻，有 効，やや有奻，無効の 4 段階に判定したるのである.

副作用については詥察するごとに閿して，有無を確 かめた.

\section{臨床成 績}

主治医の判定では著効19例（44\%)，有効13例(30\%), 中や有効 6 例 (14\%), 無効 5 例 (12\%) であり有効率 は88\%（表 $2 \mathrm{~A}$ ）であった。採点法による判定では，初 日における郜床症状を点数で表し合計し，評価日（主と して第 3 日目) の症状点数合計を除した数値を用いて表 現してある。著効すなわち第 3 日目の点数/初日の点数 が 0.30 以下は 8 例 (19\%), 有効すなわち0.31〜0.70以 下は15例 (35\%)，無効すなわち0.71以上の症例は20例 (47\%) であり，有効率53\%，第 3 日目改善率の平均は $0.80 \pm 0.79(n=43)$ であった.

この評価法は，初日および評価日の点数が高い場合に は客钼性を有するが, 初日の症状点数が 3 点以下,すな わち侮床症状がはとんど存在しない患者については，投 薬により症状の改善（点数の減少）は起こり得ない，そ こで初日の臨床症状の合計点が 3 点以下を省いて処理す ると，無効例は 12 例となり有効率 $65.7 \%$ ，改善率平均 $0.58 \pm 0.41(n=35)$ (表 2 B ) であった。

疾患別に比較してみると，歯根膜炎は19例で最も多

表 2 効果判定

\begin{tabular}{|c|c|}
\hline \multicolumn{2}{|c|}{ A）主治医判定 } \\
\hline & 例 数 \\
\hline 著 奻 & $\begin{array}{c}19 \\
(44 \%)\end{array}$ \\
\hline 有 奻 & $\begin{array}{c}13 \\
(30 \%)\end{array}$ \\
\hline 稍有奻 & $\begin{array}{c}6 \\
(14 \%)\end{array}$ \\
\hline 無 奻 & $\begin{array}{c}5 \\
(12 \%)\end{array}$ \\
\hline 有效率 & $88 \%$ \\
\hline
\end{tabular}

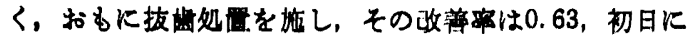
定状を呈さなかった 4 例を省く15例については改善率 0.53であった，次いで多い症例の智周周炏は12例で改 率率は 1.00 ，初日点数 3 点以上の 10 例化ついても改率率

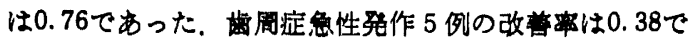

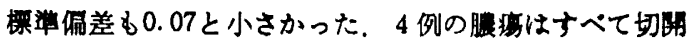
処畺し，改言率は0.64であった（黄了）。

処贯别比较では，全43例中観血如置は35例 $(81 \%)$ て 改㐭平平均 0.88 ，初日点数 3 点以上の 27 例については

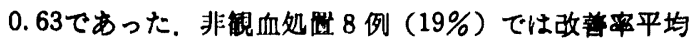

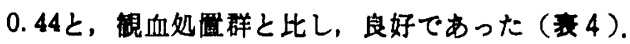

副作用については43例中 1 例，第 2 日目に腹部不快感 と吐奴を盺えたが投与中止には至らなかった。残る42例 については問影した筃囲において副作用は認められなか った.

表 3 疾患別改善事

\begin{tabular}{|c|c|c|c|}
\hline & 例数 & $\begin{array}{l}\text { 第 } 3 \text { 日目 } \\
\text { 政善 }\end{array}$ & 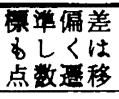 \\
\hline 相腿膜炎（全症例） & 19 & 0.63 & 0.29 \\
\hline （初日 3 点以上の例） & 15 & 0.53 & 0.24 \\
\hline 智茵周囲炎（全症例） & 12 & 1.00 & 0.86 \\
\hline （初日 3 点以上の例） & 10 & 0.76 & 0.63 \\
\hline 膿㙏 & 4 & 0.64 & 0.38 \\
\hline 齿周症急性発作 & 5 & 0.38 & 0.07 \\
\hline 埋伏歯（初日無症状） & 1 & 4.50 & $2 \rightarrow 9$ \\
\hline 枟位歯（初日無症状） & 1 & 1.00 & $2 \rightarrow 2$ \\
\hline 耳下腺炎 & 1 & 0.40 & $5 \rightarrow 2$ \\
\hline 全症例 計 & 43 & 0.80 & 0.79 \\
\hline 初日 3 点以上例 計 & 35 & 0.58 & 0.41 \\
\hline
\end{tabular}

表 4 処贯別改善事

\begin{tabular}{|c|c|c|c|}
\hline & 例数 & $\begin{array}{l}\text { 第 } 3 \text { 日目 } \\
\text { 改善 率 }\end{array}$ & 標嚾偏差 \\
\hline 猊血処置群（全例） & 35 & 0.88 & 0.85 \\
\hline （初日 3 点以上例） & 27 & 0.63 & 0.45 \\
\hline 内訳 & & & \\
\hline 拔齿（全例） & 31 & 0.91 & 0.89 \\
\hline (初日 3 点以上例) & 23 & 0.62 & 0.46 \\
\hline 切開 & 4 & 0.64 & 0.38 \\
\hline 非観血処着群 & 8 & 0.44 & 0.23 \\
\hline 全症例 & 43 & 0.80 & 0.79 \\
\hline 初日 3 点以上症例 & 35 & 0.58 & 0.41 \\
\hline
\end{tabular}




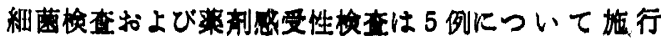
乙, 病原獭として str. viridans, anaerobic $\operatorname{gram}(-)$ 杆 菌, anaerobic $\operatorname{gram}(+)$ 杆荡, anaerobic $\operatorname{gram}(-)$ 球 菌などが分離され，いずれすAC-PC に対して（H）の 感受性を示した。

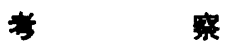

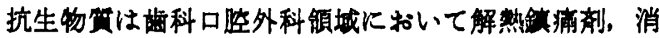

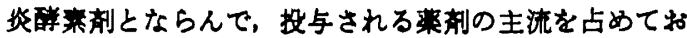

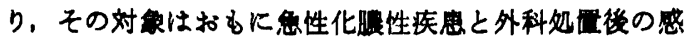
染于防である。これらの病原菌の大部分は現在なお゙合成 ベニシリンに対し感受性を有し，耐性菌の出現を防ぐ意 味においてもべニシリン系製制は第一次逪択として用い られている. シクラシリンはフンピシリンと比べてクラ 么陰性菌に対する抗菌力が弱い1)とされているか，口腔 内感染症の病原菌はおすにクラム陽性菌であり7)，今回

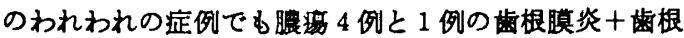

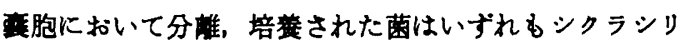
ンに対して（卅）の感受性を示したことは，症例は少な いがこのことを衰付けるすのであった，加えて，経口投

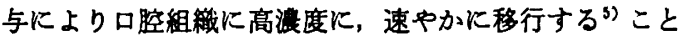
むわれわれの領域での有用性を高めるすのである.

今回われわれの使用したシクラシリン製剤であるハiト ラシン細粒について，その有效率は主治医の主観的判定 で 88\%，臨床症状採点による判定では 54\%の 有効率で あった，主治医の判定と，採点法による評価の差につい て考えるに，初日臨床症状すなわち急性炎症症状を汪之 んど呈していない症例に外科的侵襲を加えた場合，点数 の減少すなわち臨床症状の改善がみられることはなく， 逆に点数が增加することが必至であり，この点，主治医 の主钼的判定は，初日に注とんと䠛床症状が存在しない 症例に外科的侵翼を加えても後日症状が特に悪化しない 場合有効と判断しているため，採点法による評価との間 に差が生じたものと思える．外科的侵裂による点数增加 は，観血処直群の第 3 日目改善率平均か 0.88 V対し非锶 血処眉群では0.44と 2 倍の差があること，純粋に感染症 である歯周炎急性発作および膿瘍と，外科的侵裂度の比

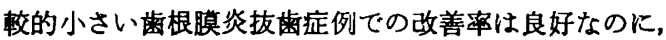

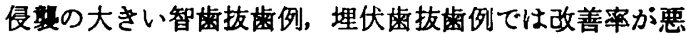

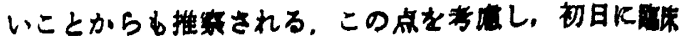

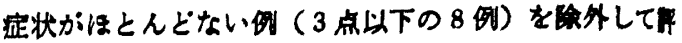

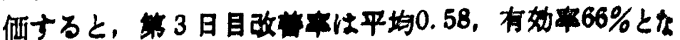

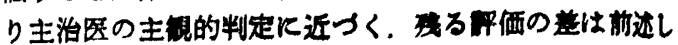
たよろに，無症状の定例に外科的边但を加光てる覀化し

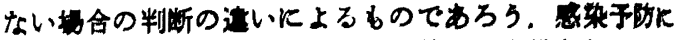

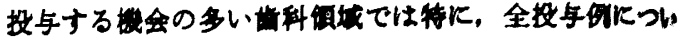

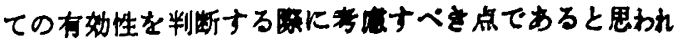
ろ.

結解

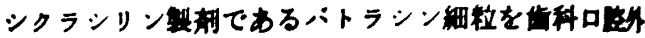

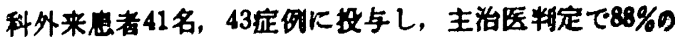

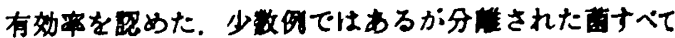

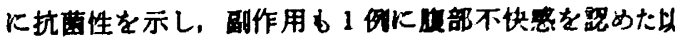
外的率なるのはなかった。

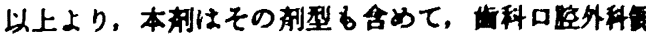
城で第一次㜊択として高い有用性をるつと考えられる。

\section{引 用女 暗}

1）中沢昭三，他：新しい合成ベニシリン Amino cyclohexyl-Penicillin K网する相菌学的研究。 Chemotherapy 18: 3111970.

2）日本抗生物算医营品

3) Rosenman, et al.: Antimicrobial activity and pharmacological distribution of $W y-4508$, an aminoalicyclic penicillin. Antimicro. Agents \& Aminocyclohexyl-Chemoth-1967: 5901968.

4) 波㲽一功, 他 : Ampicillin (anhydrous typc), Amoxycillin, Cyclacillin の血中度拈 中排泄にっいて。新薄と医床 24: 10211975.

5）佐々木次郎，他：Cyclacillin (AC-PC) の口臣

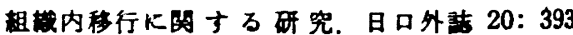
1974.

6) 中村英夫，他：シクラシリンおよびフンビシリ

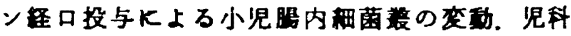
湢床 30：517 1977 .

7）常集信雄，他：東京医科齿科大学口貯外科学楮。

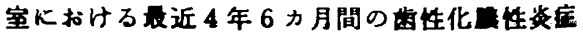

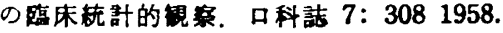

